\title{
ACETAMINOPHEN EFFECT ON FREE RADICAL OXIDATION INDICES IN RATS WITH TYPE 2 DIABETES MELLITUS
}

\author{
O. B. Furka, I. B. Ivanusa, M. M. Mykhalkiv, I. M. Klishch \\ I. HORBACHEVSKY TERNOPIL STATE MEDICAL UNIVERSITY, TERNOPIL, UKRAINE
}

Background. Acetaminophen is a drug used to relieve pain syndrome. It is used both independently and in composition of combined drugs. Type 2 diabetes is an age-related disease that is associated with a violation of insulin synthesis by pancreas.

Objective. The aim of the research was to study the effect of acetaminophen on major free radical oxidation indices of rats with type 2 diabetes mellitus in time dynamics.

Methods. We conducted two series of experiments. The first series comprised rats with type 2 diabetes mellitus and acute acetaminophen toxic lesions. The second series involved rats with type 2 diabetes mellitus and acetaminophen administration at a dose of $55 \mathrm{mg} / \mathrm{kg}$ for the period of 7 days.

Results. Administration of acetaminophen for rats with type 2 diabetes mellitus caused the increase in the content of malondialdehyde, diene and triene conjugates and Schiff bases in blood plasma and malondialdehyde, diene and triene conjugates in liver homogenate. The maximum increase in these indices was observed on the first day of the experiment. Gradually these indices decreased on the $3^{\text {rd }}, 5^{\text {th }}$ and $7^{\text {th }}$ days of the experiment.

Conclusions. Free radical oxidation increased in both series of the experiment. This process developed in rats with type 2 diabetes mellitus and acute acetaminophen toxic lesions more intensively, than in rats with type 2 diabetes mellitus and administration of acetaminophen at the highest therapeutic dose during 7 days.

KEY WORDS: acetaminophen; malondialdehyde; diene and triene conjugates; Schiff bases; diabetes mellitus.

\section{Introduction}

Acetaminophen is a drug used to relieve pain syndrome. It is used both independently and in composition of combined drugs. A long time it was considered to be the safest drug among the group of analgesics/antipyretics [1, 2]. Acetaminophen has a relatively low toxicity in therapeutic doses. However, a conscious and often uncontrolled administration of high doses of the drug causes complications that sometimes can lead to death due to hepatic insufficiency $[3,4,5]$.

Type 2 diabetes is one of the most common diseases, every year its frequency is steadily increasing. The prevalence of diabetes is associated with changes in environmental factors, especially the populations (genetic, demographic), the concentration of risk factors in the populations (increased body weight, arterial hypertension, cardiovascular diseases, lipid metabolism disorders, etc.).

Corresponding author: Olha Furka, Department of Medical Biology, I. Horbachevsky Ternopil State Medical University, 2 Yu. Slovatskoho, Ternopil, Ukraine, 46001

Phone number: +380352252584

E-mail: furkaob@tdmu.edu.ua
Considering all above, the aim of our research was to study free radical oxidation activity in rats with type 2 diabetes mellitus and acetaminophen toxic lesions.

\section{Methods}

The experiments were carried out on white rats weighing 180-220 g on a standard diet and free access to water in vivarium.

We conducted two series of experiments. In the first series toxic lesion was caused by a single intragastric administration of acetaminophen suspension in $2 \%$ starch solution for the animals at a dose of $1250 \mathrm{mg} / \mathrm{kg}\left(1 / 2 \mathrm{LD}_{50}\right)$. In the second series the suspension of acetaminophen in a $2 \%$ starch solution at a dose of $55 \mathrm{mg} / \mathrm{kg}$ was managed, which corresponds to the highest therapeutic dose during 7 days. Non-genetic form of experimental type 2 diabetes mellitus was modeled by Islam S., Choi H. method [7, 8], that is, a single intraperitoneal administration of streptozotocin solution at a dose of $65 \mathrm{mg} / \mathrm{kg}$ (Sigma, USA) to the rats, which was diluted by citrate buffer $(\mathrm{pH} 4.5)$ with the previous (15 minutes ahead) intraperitoneal nicotinamide 
administration at a dose of $230 \mathrm{mg} / \mathrm{kg}$. The rats with the same body weight, which were given the same amount of solvent (citrate buffer $\mathrm{pH}$ 4.5), were used as the control group.

In the first series of the experiment, the rats were divided into 4 groups: the $1^{\text {st }}$ group was the intact (control); the $2^{\text {nd }}$ group involved a single acetaminophen administration; the $3^{\text {rd }}$ group comprised the animals with type 2 diabetes mellitus caused by streptozotocin administration; and the $4^{\text {th }}$ group contained the rats with a single administration of acetaminophen after streptozotocin administration. In the second series of the experiment, the rats were divided into 4 groups: the $1^{\text {st }}$ group was the intact (control); the $2^{\text {nd }}$ group was with acetaminophen administration during 7 days; the $3^{\text {rd }}$ group were the animals with type 2 diabetes mellitus caused by streptozotocin administration; the $4^{\text {th }}$ group were the rats with administration of acetaminophen during 7 days after streptozotocin administration.

The animals were removed from the experiment on the $5^{\text {th }}, 3^{\text {rd }}, 5^{\text {th }}$ and $7^{\text {th }}$ days after last acetaminophen administration by euthanasia under thiopental anaesthesia. All experiments on rats were carried out according to The Guideline Principles for the Care and Use of Laboratory Animals [10].

Evaluation of the content of diene and triene conjugates was carried out by the method [6]. Determination of malondialdehyde content was carried out by the method [9]. Determination of the contents of the Schiff bases was carried

Table 1. Dynamics of content of malondialdehyde, diene and triene conjugates and Schiff bases in blood plasma of rats with type 2 diabetes mellitus and acute acetaminophen toxic lesions $(\mathrm{M} \pm \mathrm{m} ; \mathrm{n}=10)$

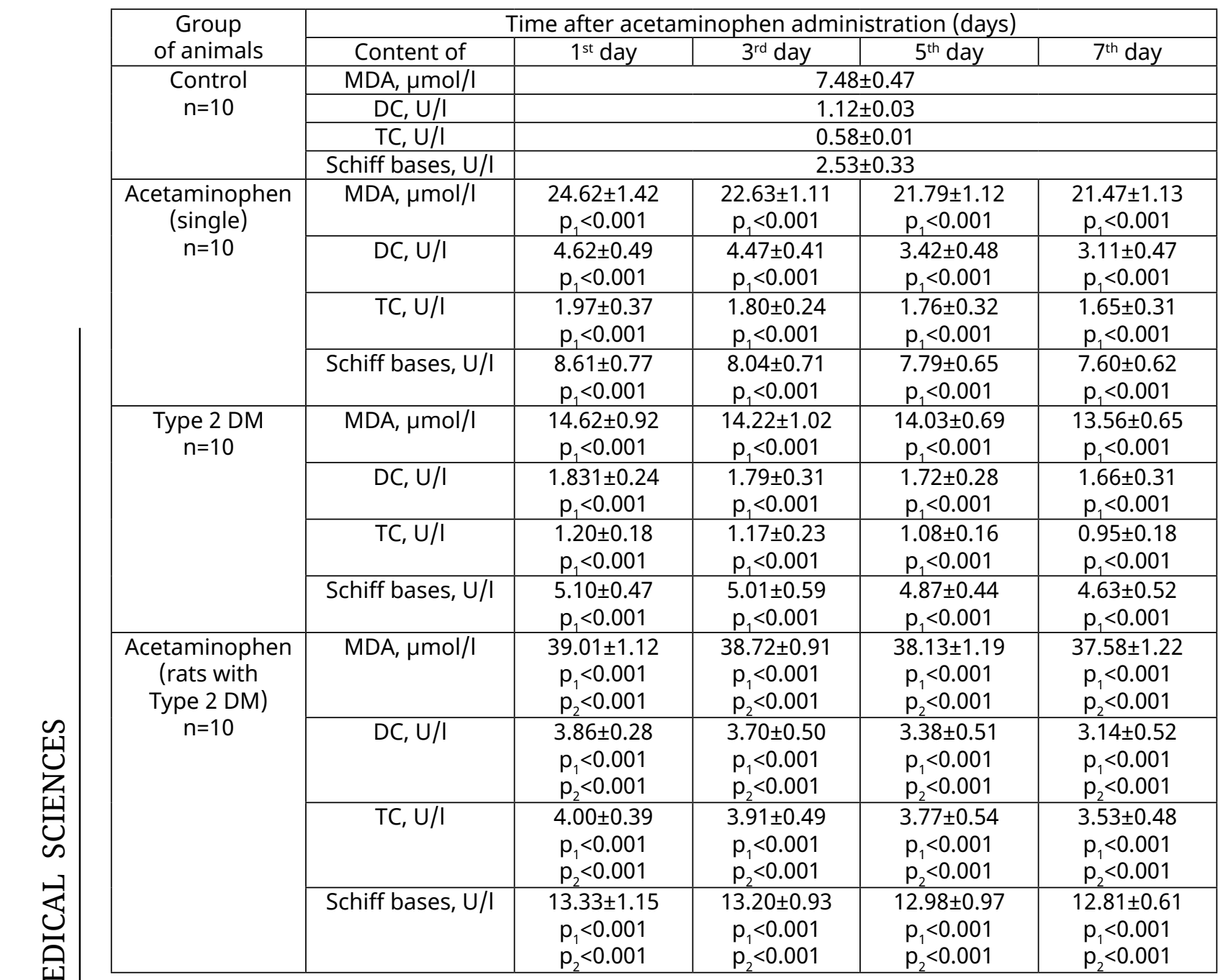

Notes: here and in the following tables

$\mathrm{p}_{1}$ - significant difference compare with control animals;

$\mathrm{p}_{2}$ - significant difference compare with the animals, which were administered with acetaminophen. 
out by the method $[12,13]$. Quantitative indices were processed statistically. The results of the experiment were processed by means of statistical program Statistica [11] using parametric Student's t test and Wilcoxon signed-rank test for non-parametric statistical hypothesis test. Changes were considered significant at $p \leq 0.05$.

\section{Results}

The content of malondialdehyde, diene and triene conjugates and Schiff bases increased in animals with lesions caused by acetaminophen and type 2 diabetes mellitus.

As presented in Table 1, the content of malondialdehyde in blood plasma increased by $229.2 \%$ on the $1^{\text {st }}$ day of the experiment in the $2^{\text {nd }}$ group of experimental animals, it increased by $95.5 \%$ in the $3^{\text {rd }}$ group of animals. The maximum of this index increase (in 5.21 times) was observed in the animals with type 2 diabetes mellitus and acute acetaminophen toxic lesions (the $4^{\text {th }}$ group). This index decreased on the $3^{\text {rd }}$ and $5^{\text {th }}$ days of the experiment. The maximal decrease of malondialdehyde content was observed on the $7^{\text {th }}$ day of the experiment in all groups of animals.

The content of diene and triene conjugates in blood plasma of the animals with single acetaminophen administration (the $2^{\text {nd }}$ group) increased in 4.11 and 3.36 times on the $1^{\text {st }}$ day of the experiment to compare with the control animals. These indices increased by $62.8 \%$ and $104.8 \%$ in the $3^{\text {rd }}$ group of animals with streptozotocin action. The content of diene conjugates increased in 3.43 times, and triene conjugates in 6.81 times in the animals with type 2 diabetes mellitus and acute acetaminophen toxic lesions (the $4^{\text {th }}$ group). These indices decreased on the $3^{\text {rd }}, 5^{\text {th }}$ and $7^{\text {th }}$ days of the experiment.

The content of Schiff bases increased in 3.4 times on the $1^{\text {st }}$ day of the experiment in the $2^{\text {nd }}$ group of experimental animals after acetaminophen administration. This index increased by $101.6 \%$ in the $3^{\text {rd }}$ group of animals with streptozotocin administration. The maximal increase of Schiff bases in 5.26 times was observed in the $4^{\text {th }}$ group of animals with type 2 diabetes mellitus and single acetaminophen administration.

According to the results (Table 2 ), the content of malondialdehyde in liver homogenate increased in 4.76 times on the $1^{\text {st }}$ day of the experiment in the $2^{\text {nd }}$ group of experimental animals to compare with the control animals, and by $60.8 \%$ in the $3^{\text {rd }}$ group of animals. The maximum of this index increase (in 5.7 times) was observed in the $4^{\text {th }}$ group of animals.

Table 2. Dynamics of content of malondialdehyde, diene and triene conjugates in liver homogenate of rats with type 2 diabetes mellitus and acute acetaminophen toxic lesions $(M \pm m ; n=10)$

\begin{tabular}{|c|c|c|c|c|c|}
\hline \multirow{2}{*}{ Group of animals } & \multicolumn{5}{|c|}{ Time after acetaminophen administration (days) } \\
\hline & Content of & $1^{\text {st }}$ day & $3^{\text {rd }}$ day & $5^{\text {th }}$ day & $7^{\text {th }}$ day \\
\hline \multirow{3}{*}{$\begin{array}{c}\text { Control } \\
n=10\end{array}$} & $\mathrm{MDA}, \mu \mathrm{mol} / \mathrm{I}$ & \multicolumn{4}{|c|}{$13.67 \pm 1.16$} \\
\hline & $\mathrm{DC}, \mathrm{U} / \mathrm{I}$ & \multicolumn{4}{|c|}{$7.83 \pm 0.26$} \\
\hline & $\mathrm{TC}, \mathrm{U} / \mathrm{I}$ & \multicolumn{4}{|c|}{$3.69 \pm 0.16$} \\
\hline \multirow{3}{*}{$\begin{array}{l}\text { Acetaminophen } \\
\text { (single) } \\
n=10\end{array}$} & $\mathrm{MDA}, \mu \mathrm{mol} / \mathrm{I}$ & $\begin{array}{c}65.10 \pm 3.57 \\
p_{1}<0.001\end{array}$ & $\begin{array}{c}64.51 \pm 3.50 \\
p_{1}<0.001\end{array}$ & $\begin{array}{c}63.67 \pm 2.41 \\
p_{1}<0.001\end{array}$ & $\begin{array}{c}62.63 \pm 2.11 \\
p_{1}<0.001\end{array}$ \\
\hline & $\mathrm{DC}, \mathrm{U} / \mathrm{I}$ & $\begin{array}{c}46.09 \pm 1.43 \\
p_{1}<0.001\end{array}$ & $\begin{array}{c}44.21 \pm 2.07 \\
p_{1}<0.001\end{array}$ & $\begin{array}{c}39.47 \pm 1.72 \\
p_{1}<0.001\end{array}$ & $\begin{array}{c}38.94 \pm 2.06 \\
p_{1}<0.001\end{array}$ \\
\hline & $\mathrm{TC}, \mathrm{U} / \mathrm{I}$ & $\begin{array}{c}17.93 \pm 0.78 \\
p_{1}<0.001\end{array}$ & $\begin{array}{c}17.18 \pm 1.56 \\
p_{1}<0.001\end{array}$ & $\begin{array}{c}16.14 \pm 1.69 \\
p_{1}<0.001\end{array}$ & $\begin{array}{c}15.38 \pm 1.28 \\
p_{1}<0.001\end{array}$ \\
\hline \multirow{3}{*}{$\begin{array}{c}\text { Type } 2 \text { DM } \\
n=10\end{array}$} & $\mathrm{MDA}, \mu \mathrm{mol} / \mathrm{I}$ & $\begin{array}{c}21.98 \pm 1.80 \\
p_{1}<0.001\end{array}$ & $\begin{array}{c}21.55 \pm 2.04 \\
p_{1}<0.001\end{array}$ & $\begin{array}{c}20.79 \pm 1.92 \\
p_{1}<0.001\end{array}$ & $\begin{array}{c}20.19 \pm 2.08 \\
p_{1}<0.001\end{array}$ \\
\hline & $\mathrm{DC}, \mathrm{U} / \mathrm{I}$ & $\begin{array}{c}23.44 \pm 1.00 \\
p_{1}<0.001\end{array}$ & $\begin{array}{c}21.66 \pm 1.50 \\
p_{1}<0.001\end{array}$ & $\begin{array}{c}20.47 \pm 1.13 \\
p_{1}<0.001\end{array}$ & $\begin{array}{c}20.19 \pm 1.70 \\
p_{1}<0.001\end{array}$ \\
\hline & $\mathrm{TC}, \mathrm{U} / \mathrm{I}$ & $\begin{array}{c}13.43 \pm 0.58 \\
p_{1}<0.001\end{array}$ & $\begin{array}{c}12.78 \pm 1.37 \\
p_{1}<0.001\end{array}$ & $\begin{array}{c}12.02 \pm 1.04 \\
p_{1}<0.001\end{array}$ & $\begin{array}{c}11.47 \pm 1.11 \\
p_{1}<0.001\end{array}$ \\
\hline \multirow{3}{*}{$\begin{array}{l}\text { Acetaminophen } \\
\text { (rats with } \\
\text { type } 2 \mathrm{DM} \text { ) } \\
\mathrm{n}=10\end{array}$} & $\mathrm{MDA}, \mu \mathrm{mol} / \mathrm{l}$ & $\begin{array}{c}77.94 \pm 2.43 \\
p_{1}<0.001 \\
p_{2}<0.001\end{array}$ & $\begin{array}{c}77.31 \pm 4.14 \\
p_{1}<0.001 \\
p_{2}<0.001\end{array}$ & $\begin{array}{c}76.53 \pm 2.00 \\
p_{1}<0.001 \\
p_{2}<0.001\end{array}$ & $\begin{array}{c}75.70 \pm 2.09 \\
p_{1}<0.001 \\
p_{2}<0.001\end{array}$ \\
\hline & $\mathrm{DC}, \mathrm{U} / \mathrm{I}$ & $\begin{array}{c}52.98 \pm 1.03 \\
p_{1}<0.001 \\
p_{2}<0.001\end{array}$ & $\begin{array}{c}51.25 \pm 1.89 \\
p_{1}<0.001 \\
p_{2}<0.001\end{array}$ & $\begin{array}{c}51.03 \pm 2.27 \\
p_{1}<0.001 \\
p_{2}<0.001\end{array}$ & $\begin{array}{c}47.34 \pm 2.34 \\
p_{1}<0.001 \\
p_{2}<0.001 \\
\end{array}$ \\
\hline & $\mathrm{TC}, \mathrm{U} / \mathrm{I}$ & $\begin{array}{c}24.24 \pm 1.49 \\
p_{1}<0.001 \\
p_{2}<0.001\end{array}$ & $\begin{array}{c}23.56 \pm 1.45 \\
p_{1}<0.001 \\
p_{2}<0.001\end{array}$ & $\begin{array}{c}22.94 \pm 1.67 \\
p_{1}<0.001 \\
p_{2}<0.001\end{array}$ & $\begin{array}{c}22.01 \pm 1.64 \\
\mathrm{p}_{1}<0.001 \\
\mathrm{p}_{2}<0.001\end{array}$ \\
\hline
\end{tabular}


The content of diene and triene conjugates in the experimental animals increased the most in the $4^{\text {th }}$ group of animals on the $1^{\text {st }}$ day of the experiment in 6.76 and 6.56 times respectively. These indices increased on the $1^{\text {st }}$ day of the experiment in 5.88 and 4.85 times in the $2^{\text {nd }}$ group, and in 2.99 and 3.63 times in the $3^{\text {rd }}$ group respectively.

The content of malondialdehyde, diene and triene conjugates, Schiff bases increased on the $1^{\text {st }}$ day of the experiment in blood plasma (Table 3) and liver homogenates (Table 4). These indices decreased on the $3^{\text {rd }}, 5^{\text {th }}, 7^{\text {th }}$ days in all series of the experiment. These changes were less pronounced than in the $1^{\text {st }}$ series of the experiment.

In the $2^{\text {nd }}$ group of experimental animals with acetaminophen administration during 7 days, the content of malondialdehyde in blood plasma on the $1^{\text {st }}$ day of the experiment increased by $126.5 \%$, in liver homogenate - by
138.6\%; diene and triene conjugates in blood plasma increased by $105.9 \%$ and $142.3 \%$, in liver homogenate increased in 3.0 and 3.2 times; Schiff bases increased by $134.3 \%$ in blood plasma to compare with control animals.

In animals with type 2 diabetes and acetaminophen administration during 7 days (the $4^{\text {th }}$ group), malondialdehyde in blood plasma increased the most in 4.13 times on the $1^{\text {st }}$ day of the experiment, it increased in 4.9 times in lever homogenate; the content of diene and triene conjugates increased in blood plasma in 3.1 and 3.2 times, in 5.7 and 4.2 times in liver homogenate; Schiff bases increased in 4.1 times in blood plasma.

\section{Discussion}

The activation of free radical processes is universal mechanism in case of toxic action of the vast majority of toxic agents. The mechanism of cell damage by free radical metabolites,

Table 3. Dynamics of content of malondialdehyde, diene and triene conjugates and Schiff bases in blood plasma of rats with type 2 diabetes mellitus and acetaminophen administration at a dose of $55 \mathrm{mg} / \mathrm{kg}$ during 7 days $(M \pm m ; n=10)$

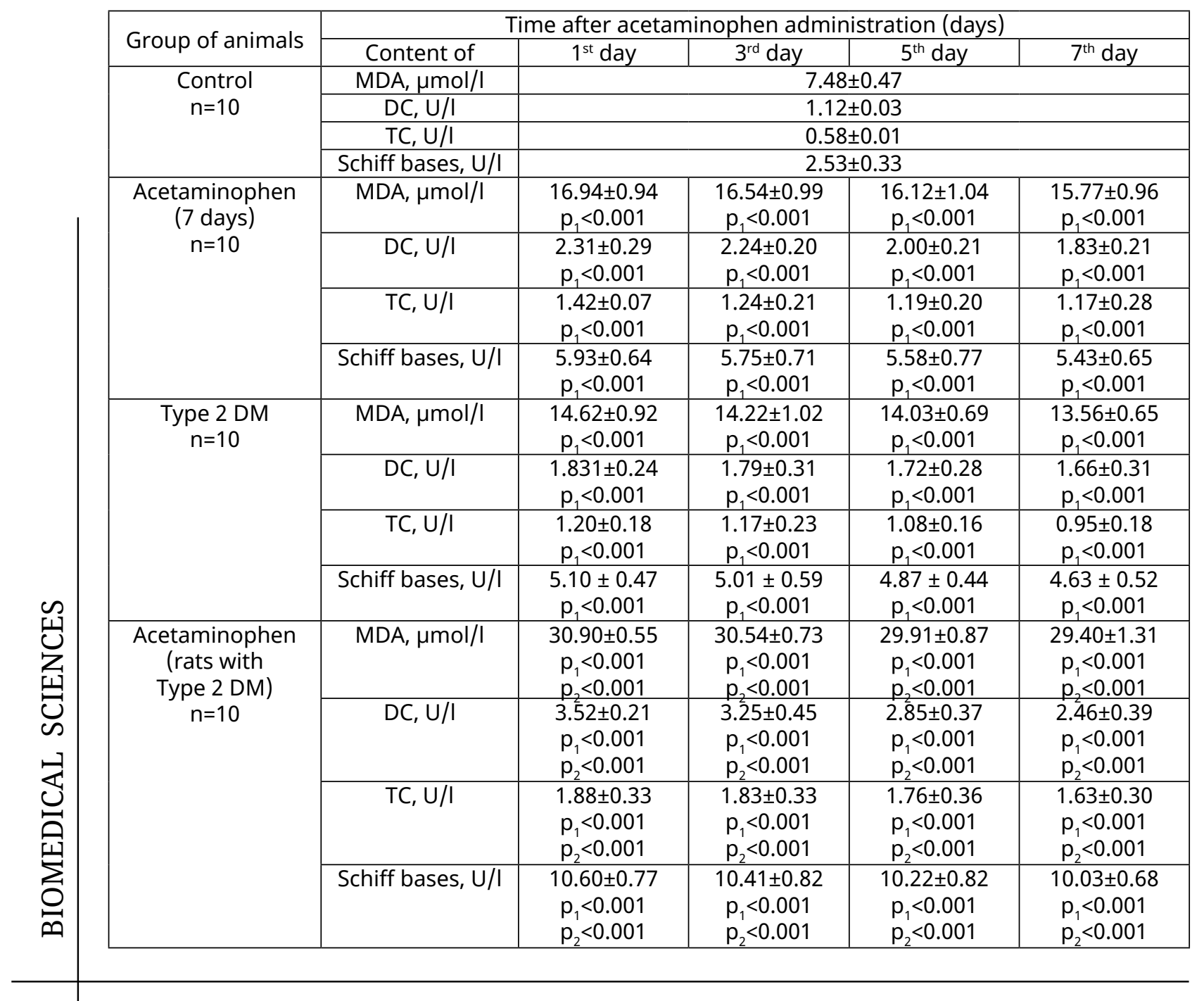


Table 4. Dynamics of content of malondialdehyde, diene and triene conjugates and Schiff bases in liver homogenate of rats with type 2 diabetes mellitus and acetaminophen administration at a dose of $55 \mathrm{mg} / \mathrm{kg}$ during 7 days $(M \pm m ; n=10)$

\begin{tabular}{|c|c|c|c|c|c|}
\hline \multirow{2}{*}{ Group of animals } & \multicolumn{5}{|c|}{ Time after acetaminophen administration (days) } \\
\hline & Content of & $1^{\text {st }}$ day & $3^{\text {rd }}$ day & $5^{\text {th }}$ day & $7^{\text {th }}$ day \\
\hline \multirow{3}{*}{$\begin{array}{c}\text { Control } \\
n=10\end{array}$} & MDA, $\mu \mathrm{mol} / \mathrm{l}$ & \multicolumn{4}{|c|}{$13.67 \pm 1.16$} \\
\hline & $\mathrm{DC}, \mathrm{U} / \mathrm{I}$ & \multicolumn{4}{|c|}{$7.83 \pm 0.26$} \\
\hline & $\mathrm{TC}, \mathrm{U} / \mathrm{I}$ & \multicolumn{4}{|c|}{$3.69 \pm 0.16$} \\
\hline \multirow{3}{*}{$\begin{array}{l}\text { Acetaminophen } \\
\text { (7 days) } \\
n=10\end{array}$} & $\mathrm{MDA}, \mu \mathrm{mol} / \mathrm{l}$ & $\begin{array}{c}32.62 \pm 1.75 \\
p_{1}<0.001\end{array}$ & $\begin{array}{c}31.83 \pm 2.78 \\
p_{1}<0.001\end{array}$ & $\begin{array}{c}31.34 \pm 1.63 \\
p_{1}<0.001\end{array}$ & $\begin{array}{c}29.79 \pm 1.84 \\
p_{1}<0.001\end{array}$ \\
\hline & $\mathrm{DC}, \mathrm{U} / \mathrm{I}$ & $\begin{array}{c}23.63 \pm 1.60 \\
p_{1}<0.001\end{array}$ & $\begin{array}{c}23.45 \pm 1.42 \\
p_{1}<0.001\end{array}$ & $\begin{array}{c}21.43 \pm 1.40 \\
p_{1}<0.001\end{array}$ & $\begin{array}{c}20.82 \pm 1.74 \\
p_{1}<0.001\end{array}$ \\
\hline & $\mathrm{TC}, \mathrm{U} / \mathrm{I}$ & $\begin{array}{c}12.02 \pm 0.79 \\
p_{1}<0.001\end{array}$ & $\begin{array}{c}11.22 \pm 0.90 \\
p_{1}<0.001\end{array}$ & $\begin{array}{c}10.91 \pm 0.99 \\
p_{1}<0.001\end{array}$ & $\begin{array}{c}10.03 \pm 0.90 \\
p_{1}<0.001\end{array}$ \\
\hline \multirow[t]{3}{*}{$\begin{array}{c}\text { Type } 2 \text { DM } \\
n=10\end{array}$} & $\mathrm{MDA}, \mu \mathrm{mol} / \mathrm{l}$ & $\begin{array}{c}21.98 \pm 1.80 \\
p_{1}<0.001\end{array}$ & $\begin{array}{c}21.55 \pm 2.04 \\
p_{1}<0.001\end{array}$ & $\begin{array}{c}20.79 \pm 1.92 \\
p_{1}<0.001\end{array}$ & $\begin{array}{c}20.19 \pm 2.08 \\
p_{1}<0.001\end{array}$ \\
\hline & $\mathrm{DC}, \mathrm{U} / \mathrm{I}$ & $\begin{array}{c}23.44 \pm 1.00 \\
p_{1}<0.001\end{array}$ & $\begin{array}{c}21.66 \pm 1.50 \\
p_{1}<0.001\end{array}$ & $\begin{array}{c}20.47 \pm 1.13 \\
p_{1}<0.001\end{array}$ & $\begin{array}{c}20.19 \pm 1.70 \\
p_{1}<0.001\end{array}$ \\
\hline & $\mathrm{TC}, \mathrm{U} / \mathrm{I}$ & $\begin{array}{c}13.43 \pm 0.58 \\
p_{1}<0.001\end{array}$ & $\begin{array}{c}12.78 \pm 1.37 \\
p_{1}<0.001\end{array}$ & $\begin{array}{c}12.02 \pm 1.04 \\
p_{1}<0.001\end{array}$ & $\begin{array}{c}11.47 \pm 1.11 \\
p_{1}<0.001\end{array}$ \\
\hline \multirow{3}{*}{$\begin{array}{l}\text { Acetaminophen } \\
\text { (rats with } \\
\text { Type } 2 \text { DM) } \\
n=10\end{array}$} & $\mathrm{MDA}, \mu \mathrm{mol} / \mathrm{I}$ & $\begin{array}{c}67.00 \pm 1.78 \\
p_{1}<0.001 \\
p_{2}<0.001\end{array}$ & $\begin{array}{c}66.54 \pm 2.63 \\
p_{1}<0.001 \\
p_{2}<0.001\end{array}$ & $\begin{array}{c}65.66 \pm 2.20 \\
p_{1}<0.001 \\
p_{2}<0.001\end{array}$ & $\begin{array}{c}65.43 \pm 2.18 \\
p_{1}<0.001 \\
p_{2}<0.001\end{array}$ \\
\hline & $\mathrm{DC}, \mathrm{U} / \mathrm{I}$ & $\begin{array}{c}44.75 \pm 1.14 \\
p_{1}<0.001 \\
p_{2}<0.001\end{array}$ & $\begin{array}{c}42.88 \pm 1.55 \\
p_{1}<0.001 \\
p_{2}<0.001\end{array}$ & $\begin{array}{c}41.51 \pm 1.67 \\
p_{1}<0.001 \\
p_{2}<0.001\end{array}$ & $\begin{array}{c}39.14 \pm 1.70 \\
p_{1}<0.001 \\
p_{2}<0.001\end{array}$ \\
\hline & $\mathrm{TC}, \mathrm{U} / \mathrm{I}$ & $\begin{array}{c}15.62 \pm 1.12 \\
p_{1}<0.001 \\
p_{2}<0.001\end{array}$ & $\begin{array}{c}15.19 \pm 1.26 \\
p_{1}<0.001 \\
p_{2}<0.001\end{array}$ & $\begin{array}{c}14.92 \pm 1.25 \\
p_{1}<0.001 \\
p_{2}<0.001\end{array}$ & $\begin{array}{c}14.42 \pm 1.25 \\
p_{1}<0.001 \\
p_{2}<0.001\end{array}$ \\
\hline
\end{tabular}

which are formed as a result of large number of biocidal xenobiotics biotransformation, including acetaminophen, involves their ability to initiate processes of lipid peroxidation and oxidation modification of proteins, covalently bind with bio-macromolecules (proteins, nucleic acids, lipids) and generate reactive oxygen intermediates (ROI), which are highly toxic and capable to initiate new chains of free radical reactions. The severity of damage effect of free radicals depends on the intensity of their production and functional ability of antioxidant system. As the result of metabolic transformations of acetaminophen, as proved by a number of researchers [1,2], free radical metabolites, as well as reactive oxygen intermediates are formed; the damage by acetaminophen is accompanied by the intensification of free radical processes. Detoxification system is exhausted due to hyperglycaemia induced by streptozotocin injections, and reactive metabolites of acetaminophen prove even more toxic damage, the intensification of reactive oxygen intermediates formation and activation of lipid peroxidation processes in particular.
Consequently, we can assert that the radical oxidation processes in the rats with type 2 diabetes and acetaminophen action increases significantly that may cause excessive formation of free radicals and violation of their neutralization.

\section{Conclusions}

Acute lesions by acetaminophen (1/2 LD $\left.{ }_{50}\right)$ of animals with type 2 diabetes causes significant increase of lipids peroxidation processes in comparison with the animals without the simulated pathological process, and nondiabetic animals, which were modeled by acetaminophen poisoning, as indicated by the increase in the concentration of diene and triene conjugates, TBA-active products, and Schiff bases.

The administration of acetaminophen at a higher therapeutic dose for the rats with hyperglycemia during 7 days was also accompanied by a significant increase in the concentration of lipid peroxidation products, but less pronounced than in cases of acute lesions. 


\section{References}

1. Stepanov YuM, Filippova AYu, Kononov IN. Medicinal lesions of liver: pathogenesis, classification, diagnosis, treatment. Pharmacist. 2006;5.

2. Ushkalova YeA. Medicinal lesions of liver. Gastroenterology. 2003;10(73):72-75.

3. Buyeverov AO. Fundamental understanding of medicinal lesions of liver. Clinical prospects of gastroenterology, hepatology. 2002;4:7-11.

4. Minushkin ON. Some hepatoprotectors in the treatment of hepatic diseases. Therapist. 2002;6:5558.

5. Sheen CL, Dillon JF, Bateman DN, et al. Paracetamol toxicity: epidemiology, prevention and costs to the health-care system. Q J Med. 2002: 95:9:609-619.

6. Volchegorskiy IA, Nalimov AG, Yarovinskiy BG, Livshits RI. Comparison of different approaches to the determination of lipid peroxidation in heptaneisopropanol extracts of blood. Questions of medical chemistry. 1989;1:127.

7. Islam S, Choi H. Nongenetic Model of Type 2 Diabetes: A Comparative Study. Pharmacology. 2007;79:243-249.
8. Islam S, Loots DT. Experimental rodent model soft type 2 diabetes: a review. Methods Find Exp Clin Pharmacol. 2009;31(4);249-261.

9. Stalnaya ID, Garishvili TG. The method for determining malonic dialdehyde by means of thiobarbituric acid. Moscow: Medicine: 1977. p. 66-68.

10. Kozhemyakin YuM, Khromov OS, Filonenko MA. The Guideline Principles for the Care and Use of Laboratory Animals. Kyiv: Avitsena; 2002. p. 156.

11. Lapach SN, Chubenko AV, Babich PN. Statistical methods in biomedical research using Excel. Kyiv: Morion; 2000. p. 320.

12. Deryugina AV, Koryagin AS, Kopylova SV, Talamanova MN. Methods of studying the stress and adaptive reactions of the body according to blood parameters. Nizhniy Novgorod: Publishing house of Nizhny Novgorod State University; 2010. p. 25.

13. Khyshiktuyev BS, Khyshiktuyeva NA, Ivanov VN. Methods of determining the products of lipid peroxidation in an exhaled breath condensate and their clinical significance. Clinical laboratory diagnostics. 1996;3:13-15. 